\title{
Contribution of Agroforestry to the Plant Communities and Community Welfare in Ternate
}

\author{
Abdul Kadir Kamaluddin ${ }^{1, *}$, Fadila Tamnge ${ }^{1}$, Mahdi Tamrin ${ }^{1}$ \\ ${ }^{I}$ Department of forestryFaculty of Agriculture, University of Khairun Ternate, Indonesia \\ *Corresponding author.Email:_dul_alzi@yahoo.com
}

\begin{abstract}
An agroforestry system is land use developed to provide economic, ecological and social benefits to improve the welfare of the community. The aim of this study are (1) to determine the contribution of agroforestry to plant diversity, and (2) to calculate the contribution of agroforestry to community welfare in Ternate. Plant diversity was Collected by using a combination method. Data of welfare community was collected by interview method. Plant diversity was analyzed by using index of Shannon Wienner and Jaccard. Data of welfare community was analyzed by using farmer income variable. There are 18, 14, and 13 types of vegetation were recorded, each of which was found in Tabona, Gambesi, and SasaVillages (Tabona; mean= 76.94, $\mathrm{SD}=80.27$; Gambesi, mean $=30.35, \mathrm{SD}=24.27$; Sasa; mean $=28.07$; $\mathrm{SD}=51.43$ ). The highest contribution of agroforestry to community income is in strata II with a percentage of $99.66 \%$.
\end{abstract}

Keywords: agroforestry, plant diversity, Ternate

\section{INTRODUCTION}

An agroforestry system is land use developed to provide economic, ecological and social benefits to improve the welfare of the community. Land management with agroforestry system aims to maintain the mount and diversity of land production. There are a diverse range of agroforestry systems and practices employed to protect and conserve water and soil resources, provide productive livestockand wildlife habitat, and produce sustainable speciality and conventional crops [1]. Implementation of these practices provides economic benefit farmer and practitioners as well as broader landscape level ecological services as well [2]. The purpose of land management with an agroforestry system is to maintain the amount and diversity of land production $[3,4,5]$.

People in Ternate Island have practiced agroforestry patterns as Gura. Gura comes from Ternate language, which means planting in the garden. Gura is a mixed garden management system that carried out for generations, but in each region has its own name and management system. Although the local knowledge system is different from each other but it all fits with socio-cultural conditions and local ecosystem. Today's agroforestry management in Ternate is still planting various types of plants. The aims of this study were (1) to identify contribution of agroforestry to plant diversity and (2) to identify contribution of agroforestry to community welfare.

\section{METHODS}

The study was conducted in Gambesi, Tabona and Sasa Villages. The location of this study was based on purposive sampling method, where the research location was known to have agroforestry land. To collect plant diversity (amount of individu and species) use vegetation analysis. To collect data of community welfare use interview method to 90 respondents. Sample plot size for plant analysis is divided into four growth rates namely seedlings, saplings, poles and trees (Figure 1).

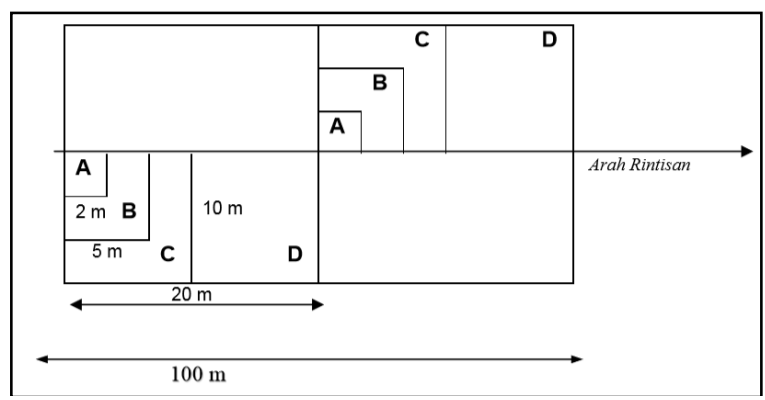

Information: A: seedling, B: sapling, C: poles, D: trees

Figure 1. The shape and size of the plot using a combination method

There are 11 variables to measure community welfare; household income, household consumption, living conditions, housing facilities, health of household members, easy access to health and medical services, education, transportation, religious life, safe from crime, and physical exercise [6].

\section{Date Analysis}

1. Importance Value Index and Plant Diversity

Data from vegetation inventory are analyzed to determine the composition and dominance of the species. The dominance of a species will be indicated by the 
Importance Value Index (INP). INP for pole and tree level vegetation is the sum of $\mathrm{KR}+\mathrm{FR}+\mathrm{DR}$ values, while for seedling and sapling level vegetation, the INP value $=\mathrm{KR}$ + FR [7].

To determine the size of plant diversity is the diversity index (Shannon-Wiener) and evenness [8].

\section{Analysis of household Income}

Calculation of total household income can be calculated by the formula of household income is income from agroforestry management plus non-agroforestry income [3]. Meanwhile percentage of income from agroforestry management is income from agroforestry management per year divided by household income per year then multiplied by $100 \%$ [9].

\section{RESULTS AND DISCUSSION}

\subsection{Agroforestry management}

Observations and interviews show that farmers have gardens that are derived from inheritance and land acquisition from other people. Agroforestry which is managed from inherited land is a cultivation system that is long-term so that the clarity of guarantees of tenure becomes very important. In its management, farmers use more experience gained from their parents and ideas between farmers. Agroforestry management is divided into several activities such as land preparation, seedbed nursery, planting, maintenance, harvesting, processing and marketing.

Experiences have shown that native trees are frequently cultivated in the farming system in Ternate. Monoculture plantations of fast growing exotic trees are predominant in forestry and consequently, in peasent livelihoods [11]. Species of exotic Syzygium aromaticum are the most popular but they are heavily criticized due to their allelopathic effect on crops [12] and understorey vegetation [13]. Therefore, farmers are obliged to encourage agroforestry systems to socio-economics benefit [14], because to introduce agroforestry aiming exclusively at producing environmental services was fail. In order to feasible and attractive for land users, agroforestry must privide favorable cost-benefit ratio within the given socioecological context [15], consider users' socio-cultural perceptions, and aim for compatibility with local livelihoods [16]

\section{A. Plant Diversity}

Based on observations, there were 18,14 , and 13 species of plants in Tabona, Gambesi and Sasa. Gambesi and Tabona have the same dominant vegetation namely $M$. fragrans, $S$. aromaticum, A. atilis, A. heterophyllus, $D$. zibethinus and $A$. catechu. While the dominant vegetation in Sasa is L. leucocephala, A. atilis, A. nidus and B. vulgaris. Each location has a different INP value, diversity and evenness index (Table 1, 2, 3).

Table 1. Important Value Index (INP) in Gambesi

\begin{tabular}{|l|c|l|c|c|c|c|}
\hline \multicolumn{1}{|c|}{ Level } & Local name & Scientific Name & Density (Ind/ha) & INP (\%) & H' & E \\
\hline Seedling & Alang-alang & Imperatasylindrica & 8000 & 77.83 & 1.12 & 0.8 \\
\hline Stake & Singkong & Manihotesculenta & 576 & 79.49 & 0.96 & 0.88 \\
\hline Pole & Cengkeh & Syzygiumaromaticum & 144 & 107.55 & 1.07 & 0.97 \\
\hline Tree & Pala & Myristicafragrans & 27 & 50.47 & 1.83 & 0.94 \\
\hline
\end{tabular}

Table 2. Important Value Index (INP) in Tabona

\begin{tabular}{|l|c|l|c|c|c|c|}
\hline \multicolumn{1}{|c|}{ Level } & Local name & Scientific Name & Density (Ind/ha) & INP (\%) & H' & E \\
\hline Seedling & Rumput teki & Cyperusrotundus & 24000 & 57.98 & 1.49 & 0.83 \\
\hline Stake & Belimbing & Averrhoacarambola & 1024 & 97.25 & 0.66 & 0.96 \\
\hline Pole & Cengkeh & Syzygiumaromaticum & 760 & 73.33 & 1.44 & 0.81 \\
\hline Tree & Cengkeh & Syzygiumaromaticum & 40 & 41.13 & 2.19 & 0.99 \\
\hline
\end{tabular}

Table 3. Important Value Index (INP) in Sasa

\begin{tabular}{|l|c|l|c|c|c|c|}
\hline \multicolumn{1}{|c|}{ Level } & Local name & Scientific Name & Density (Ind/ha) & INP (\%) & H' & E \\
\hline Seedling & Tumbuhan paku & Aspleniumnidus & 19200 & 116.33 & 0.68 & 0.42 \\
\hline Stake & Pala & Myristicafragrans & 208 & 156.25 & 0.48 & 0.69 \\
\hline Pole & Cengkeh & Syzygiumaromaticum & 180 & 144.51 & 0.77 & 0.70 \\
\hline Tree & Petai cina & Leucaenaleucocephala & 14 & 69.37 & 1.26 & 0.91 \\
\hline
\end{tabular}


For tree growth rates, the highest INP value is in Sasa Village (INP $=69.37 \%$ ), while the highest value of diversity and evenness is in Tabona Village $\left(\mathrm{H}^{\prime}=2.19 ; \mathrm{E}=0.99\right)$. Diversity becomes greater if the abundance of populations is evenly distributed [10]. Diversity does not only concern on species richness but also the evenness of the individual abundance of each species.

\section{a. Agroforestry contribution to farmers}

Agroforestry contribution to community welfare in the three locations can be seen from level of community income (Table 4). Table 4 showed that agroforestry contribute to high household income. Agroforestry has a big influence on farmers' income, which is either directly selling agroforestry products on the market or for household needs.

Table 4 Average total income from agroforestry and non-agroforestry products per year

\begin{tabular}{|c|c|c|c|c|c|c|}
\hline \multicolumn{7}{|c|}{ average income (Rp/year) } \\
\hline \multirow{2}{*}{$\begin{array}{l}\text { Stratu } \\
\mathbf{m}\end{array}$} & \multirow{2}{*}{$\begin{array}{l}\text { Land area } \\
\text { (ha) }\end{array}$} & & Agroforestry & Non agroforestri & Total & \multirow{2}{*}{$\begin{array}{c}\text { Contribusy of } \\
\text { agroforestry }(\%)\end{array}$} \\
\hline & & $\mathbf{N}$ & (Rp/year) & $(\mathrm{Rp} /$ year $)$ & $(\mathrm{Rp} /$ year $)$ & \\
\hline $\mathrm{I}$ & $>1$ & 21 & 23.438 .916 & 147.619 & 23.586 .535 & 99,37 \\
\hline II & $0.5-1$ & 35 & 36.716 .111 & 123.529 & 36.839 .641 & 99,66 \\
\hline III & $1<0.5$ & 34 & 37.737 .222 & 161.765 & 37.898 .987 & 99,57 \\
\hline \multicolumn{2}{|c|}{ Average } & 90 & 9.789 .225 & 377.778 & 10.167 .003 & 96,28 \\
\hline
\end{tabular}

\section{CONCLUSION}

There are 18, 14, and 13 species of plants in Tabona, Gambesi and Sasa. The highest INP value is in Sasa, While the highest value of diversity and evenness is in Tabona. The highest contribution of agroforestry to farmers' income is strata II $(99.66 \%)$.

\section{ACKNOWLEDGMENT}

This studi was funded by the support from DIPA Unkhair 2017. We thank Headman of Sasa, Tabona, and Gambesi. We also thank Dr. Sri D.A.S and Dr. Suratman Sudjud for comments that greatly improved the manuscript.

\section{REFERENCES}

[1] Garret HE. 2009. North American Agroforestry: an integrated science and practice, $2^{\text {nd }}$ edn. American Society of Agronomy, Madison.

[2] Jose S. 2009. Agroforestry for ecosystem service and environmental benefit: an overview. Agrofor Syst 76:1-10.

[3] Qurniati R, Marlica TA, Haryono D, 2013. Agroforestry Composition And Its Contribution Household Income In Pesawaran Indah Village District Pesawaran Lampung. Jurnal Sylva Lestari. Vol. 1 (1):pp.55-64

[4] Simatupang DP. 2011. Kontribusiproduk agroforestry terhadappendapatanrumahtangga (NagoriSimpang Raya Dasma, Kabupaten Simalungun). Universitas Sumatra Utara. Medan.

[5] Indriyanto. 2008. PengantarBudidayaHutan. Jakarta (ID); BumiPustaka.

[6] [BPS] Badan Pusat Statistik. 1991. Statistik Kesejahteraan Rumah Tangga 1991: Metode dan Analisis. Jakarta: BPS.
[7] Indriyanto. 2006. Ekologi Hutan. Jakarta (ID); BumiAksara.

[8] Magurran A. 1988. Ecological Diversity and Its Measurement. USA: Croom Helm.

[9] Tamrin M, Sundawati L, Wijayanto N. 2015. Strategi Pengelolaan Agroforestri Berbasis Aren di Pulau Bacan Kabupaten Halmahera Selatan. Jurnal Kebijakan Strategis Bidang Pertanian dan Lingkungan. Vol. 2 (3) Desember 2015: pp.243253.

[10] Desmukh I. 1992. Ekologi dan Biologi Tropika. Jakarta (ID): Yayasan Obor Indonesia.

[11] Luzar J. 2007. The political ecology of a "forest transition": Eucalyptus forestry in the southern Peruvian Andes. Ethnobot Res Appl 5: 85-93

[12] Ahmed P. 1989. Eucalyptus in agroforestry: its effect on agricultural production and economics. Agrofor Syst 8:31-38.

[13] Zhang C, Fu S. 2009. Allelophatic effects of Eucalyptus and the establishment of mixed stands of Eucalyptus and native species. For Ecol Manag 258 (7): 1391-1396.

[14] Alavalapati JRR, Shrestha RK, Stainback GA, Matta JR. 2004. Agroforestry development: an environmental economic perspective. Agrofor Syst 61: 299-310.

[15] Gausset Q. 2004. Rangking local tree needs and priorities through and interdisciplinary action research approach. J Transdiscipl Environ Stud 3(1):1-17.

[16] Reed MS. 2007. Participatory technology development for agroforestry extension: an innovation-decision approach. Afr J Agric Res 2 (8): 334-341. 